\title{
ANALISIS KEPUASAN KONSUMEN RUMAH TIPE 36 (STUDI KASUS PERUMAHAN PONDOK PERMATA SUCI GRESIK)
}

\author{
Oleh: Mas Suryanto HS *)
}

\begin{abstract}
Abstrak
Mengetahui kepuasan konsumen merupakan hal yang sangat penting dalam upaya peningkatan mutu produk perumahan, sehingga dapat bersaing dalam industri perumahan yang akhir-akhir ini berkembang dengan sangat pesat. Penelitian ini bertujuan untuk: (1) mengetahui tingkat kepuasan konsumen Perumahan Pondok Permata Suci Gresik ditinjau dari aspek lokasi, prasarana, sarana, desain, harga, dan kualitas bangunan rumah; (2) mengetahui faktor yang sangat mempengaruhi tingkat kepuasan konsumen Perumahan Pondok Permata Suci Gresik.

Penelitian ini dilakukan dengan menggunakan metode survey melalui penyebaran angket kepada penghuni perumahan, observasi, dan wawancara. Analisis data dilakukan terhadap angket yang terkumpul dengan menggunakan statistik deskriptif parametrik yaitu prosentase untuk mengetahui tingkat kepuasan konsumen dan regresi berganda untuk mengetahui faktor yang paling mempengaruhi tingkat kepuasan konsumen tersebut dengan bantuan SPSS.

Hasil penelitian menunjukkan bahwa tingkat kepuasan konsumen Perumahan Pondok Permata Suci Gresik ditinjau dari aspek lokasi 62,35\%, prasarana 62,12\%, sarana 55,93\%, desain $57,29 \%$, harga $61,31 \%$, dan kualitas bangunan rumah 60,00\%, dengan tingkat kepuasan rata-rata $59,83 \%$. Hasil analisis dengan menggunakan regresi berganda menunjukkan bahwa aspek yang sangat mempengaruhi tingkat kepuasan konsumen adalah kualitas bangunan rumah.
\end{abstract}

Kata Kunci: kepuasan konsumen, rumah

\section{PENDAHULUAN}

Seiring dengan pertumbuhan penduduk, kebutuhan akan perumahan juga ikut meningkat. Dewasa ini rumah disediakan oleh berbagai pihak baik pribadi, pemerintah, maupun swasta. Di kota-kota besar pengadaan perumahan umumnya dilakukan oleh pengembang (developer) swasta. Berdasarkan data yang ada jumlah pengembang yang menjadi anggota Real Estate Jawa Timur (REI Jatim) di Wilayah Surabaya dan sekitarnya hingga Tahun 2009 mencapai 233 buah, (www.reijatim.com).

Banyaknya pengembang menunjukkan tingkat kompetisi antara sesama semakin tinggi. Tingginya persaingan ini menyebabkan para pengembang harus berlomba dalam merebut konsumen. Berbagai cara dilakukan oleh pengembang antara lain dengan menawarkan berbagai kelebihan dari perumahan yang dibangun. Mulai dari penawaran lokasi yang strategis, sarana dan prasarana yang memanjakan konsumen, desain yang menarik, harga yang terjangkau, hingga kualitas dari rumah yang ditawarkan.

Namun demikian yang berhak melakukan penilaian terhadap produk perumahan adalah konsumen yang bersangkutan. Hasil penilaian konsumen dalam bentuk kepuasan konsumen sangat penting bagi pengembang sebagai bahan untuk melakukan perbaikan produk secara berkesinambungan. Untuk itu perlu dilakukan penelitian tentang kepuasan konsumen rumah tinggal.

Pemilihan Rumah Tipe 36, karena merupakan rumah yang banyak dikembangkan oleh pengembang karena harganya cukup terjangkau sehingga banyak dicari oleh konsumen. Gresik dipilih sebagai wilayah studi didasarkan karena merupakan salah satu kota penyangga Metropolitan Surabaya selain dengan adanya Lumpur Lapindo arah pengembangan perumahan mulai beralih dari Wilayah Sidoarjo ke wilayah ini.

Penelitian ini bertujuan untuk: (1) mengetahui tingkat kepuasan konsumen Perumahan Pondok Permata Suci Gresik ditinjau dari aspek lokasi, prasarana, sarana, desain, harga, dan kualitas bangunan rumah; (2) mengetahui faktor yang sangat mempengaruhi tingkat kepuasan konsumen Perumahan Pondok Permata Suci Gresik.

\footnotetext{
*) Dosen Teknik Sipil

Universitas Negeri Surabaya
} 
Penelitian ini diharapkan akan memberikan masukan kepada pengembang perumahan terhadap kepuasan konsumen dan faktor mana yang sangat menentukan tingkat kepuasan tersebut. Masukan tersebut diharapkan dapat menjadi tambahan informasi dalam perencanaan pembangunan perumahan saat ini atau di kemudian hari. Selain tentunya sebagai tambahan referensi tentang bagaimana mengukur dan menganalisis kepuasan konsumen rumah tinggal dan perencanaan pembangunan perumahan yang sesuai dengan kebutuhan konsumen.

\section{KAJIAN PUSTAKA}

\section{Perumahan}

Bila dikaji melalui pengertian yang tertuang dalan Undang-undang Nomor 4 Tahun 1992 tentang Perumahan dan Pemukiman, perumahan adalah kelompok rumah yang berfungsi sebagai lingkungan tempat tinggal atau lingkungan hunian yang dilengkapi dengan sarana dan prasarana lingkungan. Bagi sebuah lingkungan perkotaan, kehadiran lingkungan perumahan sangatlah penting dan berarti karena bagian terbesar pembentuk struktur ruang perkotaan adalah lingkungan pemukiman. Karena itu munculnya permasalahan pada suatu pemukiman akan menimbulkan dampak langsung terhadap permasalahan perkotaan secara menyeluruh. Dengan kata lain dapat disimpulkan bahwa baik dan buruknya sistem perkotaan dipengaruhi oleh baik dan buruknya lingkungan pemukiman.

Untuk membuat sebuah perencanaan perumahan yang betul-betul dapat menjawab tuntutan pembangunan perumahan dan pemukiman maka perlu dipertimbangkan secara matang aspekaspek perencanaannya. Keberhasilan pembangunan perumahan sebagai bagian dari program pembangunan nasional memang tidak lepas dari aspek-aspek perencanaan yang harus dipenuhinya. Dengan memperhatikan aspek-aspek perencanaan sepanjang pembangunannya, diharapkan baik arah maupun laju pembangunan perumahan akan dapat mencapai suatu kondisi dimana jumlah dan kualitasnya sesuai dengan tuntutan dan kebutuhan masyarakat.

Aspek-aspek perencanaan yang mendasari perencanaan perumahan tersebut antara lain (Suparno Sastra M. \& Endi Marlina, 2006):

a. Lingkungan, merupakan hal utama yang harus dipertimbangkan dalam perencanaan perumahan. Manajemen lingkungan yang baik dan terarah sangat diperlukan karena lingkungan suatu perumahan merupakan faktor yang sangat menentukan dan keberadaannya tidak boleh diabaikan. Hal tersebut dapat terjadi karena baik dan buruknya kondisi lingkungan akan berdampak terhadap penghuni perumahan tersebut.

b. Daya beli (affordability), merupakan hal yang perlu diantisipasi mengingat kemampuan rata-rata (kemampuan daya beli) masyarakat pada wilayah yang satu dengan yang lain tidak sama. Bahkan jika melihat data tentang kebutuhan akan rumah tinggal di Indonesia secara umum, maka kemampuan masyarakat untuk membeli rumah masih berada di bawah garis kemampuan standar.

\section{Kepuasan Konsumen}

Kepuasan yang berasal dari kata satisfaction adalah kata dari bahasa latin, yaitu Satis yang berarti enough atau cukup dan facere yang berarti to do atau melakukan (Irawan Handi, 2003). Jadi, produk atau jasa yang bisa memuaskan konsumen adalah produk atau jasa yang sanggup memberikan sesuatu yang dicari oleh konsumen sampai pada taraf cukup.

Menurut Engel kepuasan konsumen adalah suatu keadaan yang akan terjadi bila keinginan, kebutuhan dan harapan dari konsumen terhadap suatu produk dapat terpenuhi. Menurut manajer berpengalaman Tom Peters pengukuran kepuasan konsumen untuk mengetahui kualitas dari suatu produk adalah suatu hal yang relevan karena pertama, perasaan puas umumnya berdasarkan suatu observasi dari pengukuran terhadap kekurangan atau kesempurnaan suatu produk. Kedua, keluhan dari seorang konsumen umumnya menunjukkan adanya suatu masalah pada produk tersebut. Kepuasan konsumen adalah sebuah rasio antara kualitas yang diterima dengan kebutuhan, keinginan dan harapan, (Timoticin Kwanda, 2001).

Menurut Mowen pada tahap evaluasi setelah pasca pembelian, kepuasan konsumen merupakan elemen yang penting. Kepuasan akan tercapai bila terjadi kesamaan antara pengalaman mendapatkan dan menggunakan produk dengan harapan yang diinginkan oleh konsumen terhadap kualitas produk yang didapatkan. Harapan konsumen terhadap suatu produk merupakan suatu standar untuk dibandingkan dengan keadaan produk yang 
sesungguhnya. Tingkat dari performa produk yang diharapkan dapat mencapai kepuasan konsumen dipengaruhi oleh faktor-faktor yaitu keadaan produk sendiri, promosi, pengaruh dari kompetitor dan karakterisitik konsumen, (Timoticin Kwanda, 2001).

\section{Kepuasan Penghuni Perumahan}

Kepuasan penghuni perumahan ditentukan oleh beberapa faktor, antara lain:

a. Lokasi

Menurut Keputusan Menteri PU Nomor 378/KPTS/1987 tentang Pengesahan 33 Standar Konstruksi Bangunan Indonesia dan Pedoman Teknik Pembangunan Perumahan Sederhana Tidak Bersusun, keadaan dari lokasi perumahan harus memenuhi kriteria sebagai berikut:

1. Tersedia lahan yang cukup bagi pembangunan lingkungan perumahan baru minimum 50 unit rumah yang dilengkapi dengan prasarana dan sarana lingkungan.

2. Bebas dari polusi udara, polusi suara, polusi air dan bebas banjir.

3. Mempunyai aksesibilitas (daya jangkau) yang baik dan mudah serta aman mencapai tempat kerja.

b. Prasarana dalam lingkungan perumahan Prasarana yang harus dimiliki dalam lingkungan perumahan meliputi (Timoticin Kwanda, 2001):

1. Jalan, merupakan prasarana lingkungan berupa jalan lokal sekunder I yaitu jalan setapak dan jalan kendaraan memiliki standar lebar badan jalan minimal 1,5 meter dan 3,5 meter.

2. Air limbah, prasarana untuk air limbah permukiman yaitu septictank dan bidang resapan.

3. Air hujan, setiap lingkungan perumahan harus dilengkapi dengan sistem pembuangan air hujan, sehingga lingkungan perumahan bebas dari genangan air.

4. Air bersih, rumah, dan lingkungan perumahan harus mendapatkan air bersih yang cukup serta harus tersedia sistem plumbing meteran air.

5. Penyediaan listrik untuk perumahan, satu unit rumah minimum disediakan jatah 450 VA dan instalasi penerangan untuk jalan umum.

c. Sarana dalam lingkungan perumahan

Pada daerah perumahan harus disediakan sarana-sarana seperti sarana pendidikan, kesehatan, peribadatan, perbelanjaan, sarana olahraga, dan taman yang tidak dapat dipisahkan dari kehidupan penduduk.

d. Desain bangunan

Desain bangunan tidak akan terlepas dari denah rumah. Sebagai dasar pengembangan perencanaan denah yang baik harus mengandung unsur fungsi, teknologi, dan estetika. Fungsi rumah tentunya adalah sebagai tempat berlindung dan sebagai tempat untuk segala aktivitas penghuninya. Teknologi berarti bentuk struktur atau susunan rumah diatur mengikuti cara tertentu. Dengan struktural yang jelas maka orang yang berada di dalamnya akan merasa aman dan nyaman. Estetika ialah sesuatu yang mengekspresikan kesan-kesan agung dan luhur melalui cara menyajikan kesempurnaan. Keindahan terdiri dari dua unsur yaitu keindahan bentuk dan keindahan ekspresi atau keindahan lahir dan keindahan batin.

e. Harga

Faktor harga juga turut menentukan terhadap pembelian rumah. Harga rumah dan tanah yang ditawarkan oleh pengembang perumahan relatif mahal. Hal ini disebabkan banyaknya biayabiaya yang harus dipenuhi dalam pembangunan perumahan antara lain biaya perijinan, biaya pengukuran, biaya pembebasan tanah, biaya pembangunan sarana dan prasarana, biaya pembangunan rumah, dan biaya lain-lain. Harga yang terlalu mahal sedangkan kualitas dan fasilitas penunjang yang tidak sesuai dengan keinginan masyarakat, menyebabkan rumah tersebut tidak akan laku dijual. Penentuan harga penjualan barang atau jasa pada dasarnya mengikuti analisis perhitungan dengan prinsip besarnya harga sekarang (PV) untuk semua biaya adalah besarnya harga sekarang (PV) untuk semua pemasukan pada tingkat suku bunga tertentu (Robert J. Kodoatie 1995). Dalam menentukan harga jual rumah terdapat beberapa hal yang harus diperhatikan, antara lain:

1. Harga tanah matang dan harga bangunan perumahan termasuk sarana dan prasarana.

2. Harga bangunan perumahan sudah termasuk biaya sertifikat, ijin mendirikan bangunan (IMB), akta jual beli/PPAT, PDAM, biaya penyambungan PLN, dan biaya proses KPR Bank (jika pembelian dilakukan dengan kredit). 
3. Harga bangunan tidak mengikat dan sewaktu-waktu bisa berubah sesuai dengan harga pasar.

f. Kualitas bangunan rumah

Menurut Keputusan Menteri PU Nomor 20/KPTS/1986 tentang Pedoman Teknik Pembangunan Perumahan Sederhana Tidak Bersusun faktor kualitas bangunan rumah sederhana memiliki persyaratan teknik, yaitu sebagai berikut:

1. Kelengkapan bangunan, seperti: plumbing, air bersih, air limbah, dan listrik.

2. Struktur komponen dan bahan bangunan dapat menahan semua beban dan gaya termasuk gempa bumi yang bekerja pada bangunan sesuai fungsinya dan mempunyai keawetan minimum 5 tahun untuk susunan non struktur, dan minimm 20 tahun untuk susunan struktur.

\section{METODE PENELITIAN}

Penelitian ini merupakan sebuah penelitian deskriptif, dimana hasil dari penelitian ini tidak merupakan suatu penemuan teori yang baru, melainkan hanya menggambarkan sifat suatu keadaan yang sementara terjadi tentang tingkat kepuasan konsumen penghuni Perumahan Pondok Permata Suci Gresik. Kepuasan konsumen dinilai terhadap aspek lokasi, prasarana, sarana, desain, harga, dan kualitas bangunan rumah yang telah dibeli dan didiami.

Populasi pada penelitian ini adalah seluruh penghuni Rumah Tipe 36 di Perumahan Pondok Permata Suci Gresik sejumlah 658 unit, dengan jumlah sampel 66 orang (berdasarkan angket yang terkumpul). Variabel terikat pada penelitian ini adalah tingkat kepuasan konsumen, sedangkan variabel bebas adalah lokasi, prasarana, sarana, desain, harga, dan kualitas bangunan rumah.

Data primer pada penelitian ini diperoleh melalui angket yang telah diuji validitas (formula korelasi produk momen) dan reliabilitasnya (metode alpha). Angket uji coba kuesioner yang terkumpul 12 buah. Dari 62 pertanyaan yang diuji, hanya 56 pertanyaan yang valid dan reliable. Pertanyaan yang tidak valid antara lain jarak perumahan ke tempat kerja, sarana angkutan umum, sarana keamanan lingkungan, jarak antar rumah, luas KM/WC, luas teras, pembayaran dengan KPR dan tunai yang ditentukan developer, dan struktur bangunan.
Aspek lokasi pertanyaan yang valid dan reliable adalah jarak perumahan ke pusat kota, pasar, tempat ibadah, sekolah, dan rumah sakit. Aspek prasarana pertanyaan yang valid dan reliable adalah jalan perumahan, saluran air hujan, PDAM, PLN, dan Telepon. Aspek sarana pertanyaan yang valid dan reliable adalah penataan lahan, taman, fasilitas kesehatan, air bersih, penerangan jalan, telepon umum, perbelanjaan, tempat ibadah, hiburan dan olahraga.

Aspek desain pertanyaan yang valid dan reliable adalah ruang kosong, kesesuaian dengan transaksi awal, sirkulasi ruangan, ruang luar, ventilasi, perletakan ruang, luas ruang tidur, luas dapur, luas ruang keluarga, luas ruang makan, luas taman, dan warna cat. Aspek harga pertanyaan yang valid dan reliable adalah harga termasuk sertifikat, IMB, akta jual/beli, PDAM, KPR, PLN, dan perubahan harga. Aspek kualitas pertanyaan yang valid dan reliable adalah kelengkapan bangunan, penerangan alami, penghawaan alami, cat luar, cat dalam, cat kusen, material kayu untuk kusen dan pintu, jendela, material kayu plafon dan atap, plesteran dinding, dan dampak peningkatan mutu bahan bangunan terhadap kenaikan harga rumah.

Responden mengisi angket yang berisi pertanyaan aspek-aspek tersebut di atas yang pada dasarnya merupakan penilaian tingkat kepuasan mereka terhadap rumah yang telah dibeli dan didiami. Penilaian ini dilakukan dengan menggunakan Skala Likert (1 - 4). Responden cukup melingkari Angka 1 bila sangat tidak puas, 2 bila tidak puas, 3 bila puas, dan 4 bila sangat puas. Sedangkan data sekunder diperoleh melalui observasi, wawancara, dan dokumentasi. Observasi dilakukan dengan mengunjungi dan mengamati Perumahan Pondok Permata Suci Gresik. Wawancara dilakukan dengan pengelola perumahan, dan dokumentasi dilakukan dengan mempelajari gambar dan brosur perumahan.

Analisis data diawali dengan melakukan uji statistik data untuk menentukan statistik yang akan dipakai pada penelitian ini. Uji statistik data dilakukan dengan menggunakan uji normalitas (One-Sample Kolmogrov-Smirnov Test) dan homoginitas (Levene Test) data. Jika data berdistribusi normal dan variannya homogin, maka pengolahan dan analisis datanya menggunakan statistik parametrik, sedangkan jika tidak maka harus menggunakan statistik non parametrik. 
Pengukuran tingkat kepuasan konsumen dihitung dengan menggunakan rumus (Johanes Supranto, 2001):

dimana,

$$
\mathrm{P}=\frac{\sum(\mathrm{JF} \times \mathrm{S})}{\sum(\mathrm{JR} \times \mathrm{ST})} \times 100 \%
$$

$$
\begin{aligned}
\mathrm{P} & =\text { Prosentase }(\%) \\
\mathrm{JF} & =\text { Jumlah Frekuensi } \\
\mathrm{S} & =\text { Skor } \\
\mathrm{JR} & =\text { Jumlah Responden } \\
\mathrm{ST} & =\text { Skor Tertinggi }
\end{aligned}
$$

Untuk mengetahui faktor yang sangat mempengaruhi kepuasan konsumen digunakan regresi berganda yang didahului dengan uji autokorelasi. Persamaan umum uji regresi berganda adalah ( $R$. Gunawan Sudarmanto, 2005): dimana,

$$
Y=a+b_{1} X_{1}+b_{2} X_{2}+b_{3} X_{3}+b_{4} X_{4}+b_{5} X_{5}+b_{6} X_{6}
$$

$$
\begin{aligned}
& \mathrm{Y}=\text { Kepuasan Konsumen } \\
& \mathrm{a}, \mathrm{b}=\text { Parameter Variabel Bebas } \\
& \mathrm{X}_{1}=\text { Lokasi } \\
& \mathrm{X}_{2}=\text { Prasarana } \\
& \mathrm{X}_{3}=\text { Sarana } \\
& \mathrm{X}_{4}=\text { Desain } \\
& \mathrm{X}_{5}=\text { Harga } \\
& \mathrm{X}_{6}=\text { Kualitas Rumah }
\end{aligned}
$$

Pengolahan data mulai dari uji validitas, reliabilitas, normalitas, homoginitas, autokorelasi, dan regresi berganda dilakukan dengan bantuan SPSS.

\section{HASIL PENELITIAN DAN PEMBAHASAN 1. Gambaran Umum Objek Penelitian}

Penelitian ini dilakukan di Perumahan Pondok Permata Suci Gresik yang terletak di JI. K.H. Syafi'i dengan developer P.T. Bumi Lingga Pertiwi. Sebelah barat perumahan berbatasan dengan Perkampungan Warga Suci, sebelah timur berbatasan dengan Jalan Tol Surabaya-Gresik, sebelah utara berbatasan dengan Perkampungan Warga Desa Beganden Manyar, dan sebelah selatan berbatasan dengan Jalan Raya K.H. Syafi'i. Jarak dari Perumahan Pondok Permata Suci ke pusat kota 12 km, jarak ke sekolah SMA terdekat $5 \mathrm{~km}$, sedangkan jarak ke rumah sakit terdekat 2,5 km.

Prasarana yang ada di Perumahan Pondok Permata Suci ini diantaranya adalah jalan sekitar perumahan dengan lebar $6 \mathrm{~m}$, saluran air hujan (roil/got), PDAM, PLN, dan jaringan telepon. Sarana di Perumahan Pondok Permata Suci ini diantaranya adalah tempat ibadah (masjid), pasar/swalayan (Nanda Swalayan).

Dengan ukuran rumah $6 \times 6 \mathrm{~m}$ desain rumah ini terdiri dari teras, ruang tamu, dua ruang tidur, dapur, KM/WC, dan tempat cuci.
Desain Tampak Depan dan Denah Rumah Tipe 36 Pondok Permata Suci Gresik dapat dilihat pada Gambar 1 dan 2. Harga Rumah Tipe 36 terdiri dari dua macam, yaitu: (1) jika dibayar secara tunai harganya $\mathrm{Rp}$ 91.690.000,-; (2) jika dibayar dengan menggunakan KPR (Kredit Pemilikan Rumah) dengan uang muka $\mathrm{Rp}$ 18.690.000,00 maka untuk cicilan 5 tahun, per bulannya $\mathrm{Rp} 1.547 .445,-$, cicilan 10 tahun per bulannya $\mathrm{Rp} 960.525,-$, dan cicilan 15 tahun per bulannya $\mathrm{Rp} 780.002,-$.

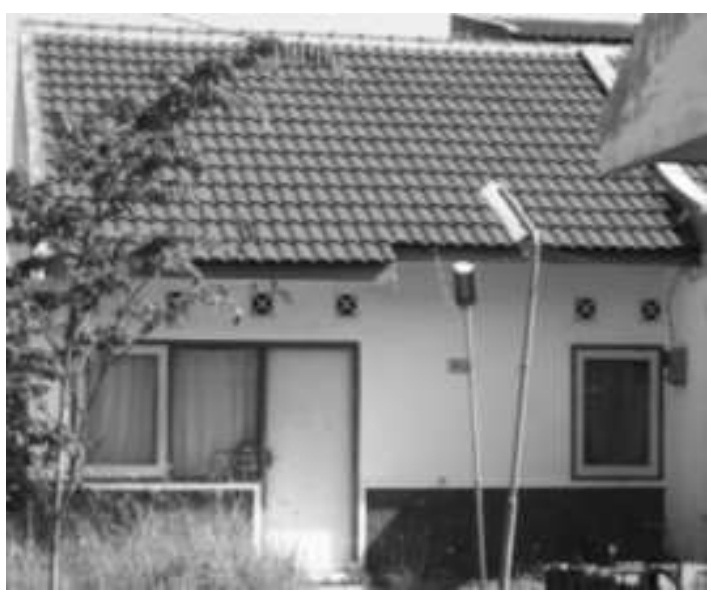

Gambar 1. Tampak Depan Rumah

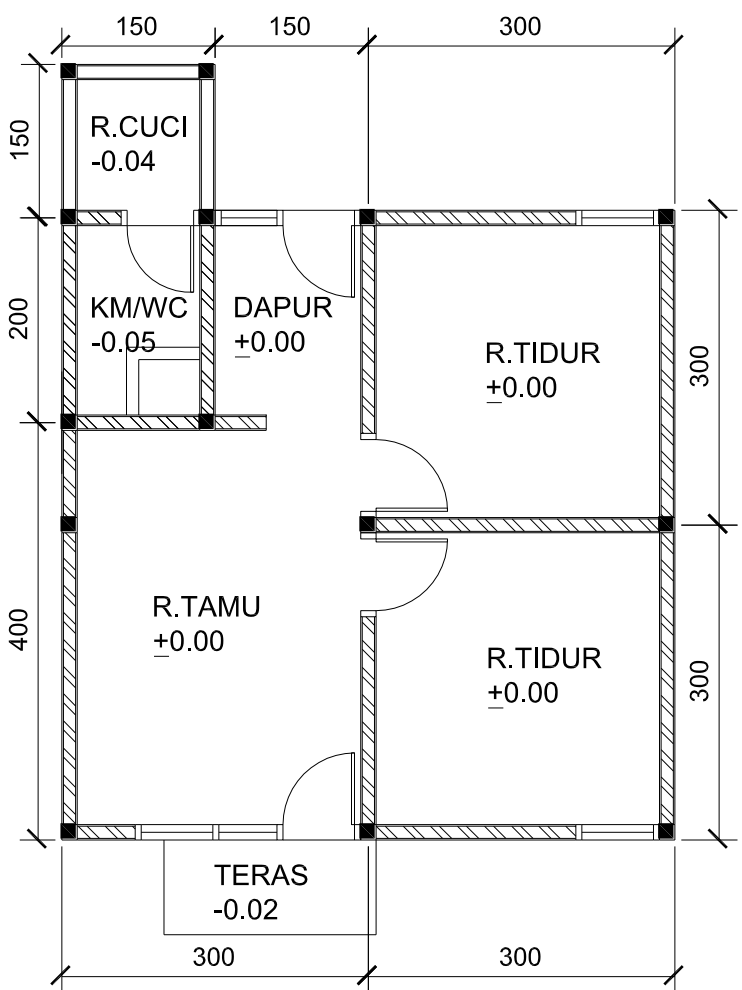

Gambar 2. Denah Rumah 
Dari segi kualitas bangunan rumah dalam hal ini adalah mutu bahan bangunan yang dipakai, maka Rumah Tipe 36 di Perumahan Pondok Permata Suci Gresik ini menggunakan struktur beton bertulang dengan material pasir dan kerikil dari Kertosono, semen menggunakan Semen Gresik dengan pondasi menggunakan beton plat menerus. Material finishing untuk dinding menggunakan batako holibrick (HB) diplester dan dicat, konstrukasi rangka atap menggunakan meranti yang diawetkan dengan TIR, atap menggunakan genteng beton yang dicat produksi Cahaya Purnama, kusen menggunakan kayu kamper, gewel menggunakan batako diplester dan dicat, dan lantai menggunakan Keramik Mulia $30 \times 30 \mathrm{~cm}$.

\section{Uji Statistik Data}

Uji statistik data dilakukan untuk mengetahui jenis pengolahan data secara statistik, yaitu parametrik atau non parametrik. Uji statistik data terdiri dari uji normalitas dan homoginitas data. Jika data berdistribusi normal dan memiliki varian yang homogin, maka pengolahan datanya dapat dilakukan dengan menggunakan statistik parametrik, jika tidak maka pengolahan datanya harus menggunakan statistik non parametrik. Uji normalitas data pada penelitian ini menggunakan One-Sample Kolmogrov-Smirnov Test, dan uji homoginitas data menggunakan Levene Test.

Uji normalitas data dilakukan dengan ketentuan (R. Gunawan Sudarmanto, 2005):

a. Jika nilai signifikasi (nilai probabilitas) > 0,05 maka dikatakan berdistribusi normal.

b. Jika nilai signifikasi (nilai probabilitas) < 0,05 maka dikatakan berdistribusi tidak normal.

Dengan menggunakan Uji One-Sample Kolmogrov-Smirnov Test dan diolah dengan SPSS, maka diperoleh hasil sesuai dengan Tabel 1. Dari Tabel 1 dapat dilihat bahwa nilai signifikansi [Asymp. Sig. (2-tiled)] untuk lokasi, prasarana, sarana, desain, harga, dan kualitas berturut-turut adalah 0,065, 0,056, 0,333, 0,597, 0,115, 0,466 > 0,05. Dengan demikian maka dapat dikatakan bahwa data berdistribusi normal.

Tabel 1. Hasil Uji Normalitas Data dengan One-Sample Kolmogrov-Smirnov Test

\begin{tabular}{|c|c|c|c|c|c|c|c|}
\hline & & Lokasi & Prasarana & Sarana & Desain & Harga & Kualitas \\
\hline $\mathrm{N}$ & & 66 & 66 & 66 & 66 & 66 & 66 \\
\hline \multirow{2}{*}{ Normal Parameter ${ }^{\mathrm{a}, \mathrm{b}}$} & Mean & 12.4697 & 12.4394 & 20.1364 & 27.5606 & 17.1667 & 23.9697 \\
\hline & Std. Deviation & 1.6569 & 1.4479 & 2.7225 & 3.0641 & 2.5334 & 3.2343 \\
\hline \multirow[t]{3}{*}{ Most Extreme } & Absolute & 161 & 165 & 116 & 095 & 147 & 105 \\
\hline & Positive & 161 & 165 & 103 & 095 & 147 & 083 \\
\hline & Negative & 110 & 132 & 116 & 087 & 114 & 105 \\
\hline Kolmagorov Smirnov Z & & 1.308 & 1.338 & 946 & 768 & 1.195 & 850 \\
\hline Asymp. Sig. (2 - tailed) & & 065 & 056 & 333 & 597 & 115 & 466 \\
\hline
\end{tabular}

Sumber: Hasil Pengolahan Data

Uji homoginitas data dilakukan dengan ketentuan (R. Gunawan Sudarmanto, 2005):

1. Jika nilai signifikasi (nilai probabilitas) > 0,05 maka dikatakan bervarian homogin.

2. Jika nilai signifikasi (nilai probabilitas) < 0,05 maka dikatakan tidak bervarian homogin.

Dengan menggunakan Uji Levene Test dan diolah dengan menggunakan SPSS, maka diperoleh hasil sesuai dengan Tabel 2. Dari Tabel 2 dapat dilihat bahwa nilai signifikansi [Sig.] untuk lokasi, prasarana, sarana, desain, harga, dan kualitas masing-masing $0,675,0,263,0,536,0,117,0,829,0,936>$ 0,05 . Sehingga dikatakan bahwa data bervarian homogin, yang berarti berasal dari populasi yang sama.

Tabel 2. Hasil Uji Homoginitas dengan Levene Test

\begin{tabular}{lcccc}
\hline & Levene Statitistic & df 1 & df 2 & Sig \\
\hline Lokasi & 396 & 2 & 63 & 675 \\
Prasarana & 1.364 & 2 & 63 & 263 \\
Sarana & 631 & 2 & 63 & 536 \\
Desain & 1.780 & 2 & 63 & 177 \\
harga & 188 & 2 & 63 & 826 \\
Kualitas & 066 & 2 & 63 & 936 \\
\hline \multicolumn{2}{l}{ Sumber: Hasil Pengolahan Data } & & &
\end{tabular}


Dari hasil uji normalitas dan homoginitas tersebut di atas menunjukkan bahwa data berdistribusi normal dengan varian yang homogin. Artinya bahwa data yang telah dikumpulkan telah memiliki pola tertentu sehingga data diolah dengan menggunakan statistik parametrik.

\section{Analisis Tingkat Kepuasan Konsumen}

Analisis tingkat konsumen diukur berdasarkan hasil penilaian yang diisi pada angket yang telah disebarkan, kemudian dianalisis dengan menggunakan rumus (Johanes Supranto, 2001): dimana

$$
\mathrm{P}=\frac{\sum(\mathrm{JF} \times \mathrm{S})}{\sum(\mathrm{JR} \times \mathrm{ST})} \times 100 \%
$$

$$
\begin{aligned}
\mathrm{P} & =\text { Prosentase }(\%) \\
\mathrm{JF} & =\text { Jumlah Frekuensi } \\
\mathrm{S} & =\text { Skor } \\
\mathrm{JR} & =\text { Jumlah Responden }
\end{aligned}
$$

$\mathrm{ST}=$ Skor Tertinggi

Sebagai contoh perhitungan dapat dilihat untuk aspek lokasi sub jarak perumahan ke pusat kota 6 reponden menjawab sangat tidak puas (1), 33 responden menjawab tidak puas (2), 23 responden menjawab puas (3), dan 4 responden menjawab sangat puas (4). Tingkat kepuasan konsumen untuk aspek lokasi sub jarak perumahan ke pusat kota, dapat dihitung:

$$
\begin{aligned}
P & =\frac{\sum(J F \times \text { S })}{\sum(J R \times S T)} \times 100 \% \\
& =\frac{(6 \times 1)+(33 \times 2)+(23 \times 3)+(4 \times 4)}{(66 \times 4)} \times 100 \% \\
& =59,47 \%
\end{aligned}
$$

Hasil perhitungan untuk aspek yang lain dapat dilihat pada Tabel 3 .

Tabel. 3 Hasil Perhitungan Tingkat Kepuasan Konsumen

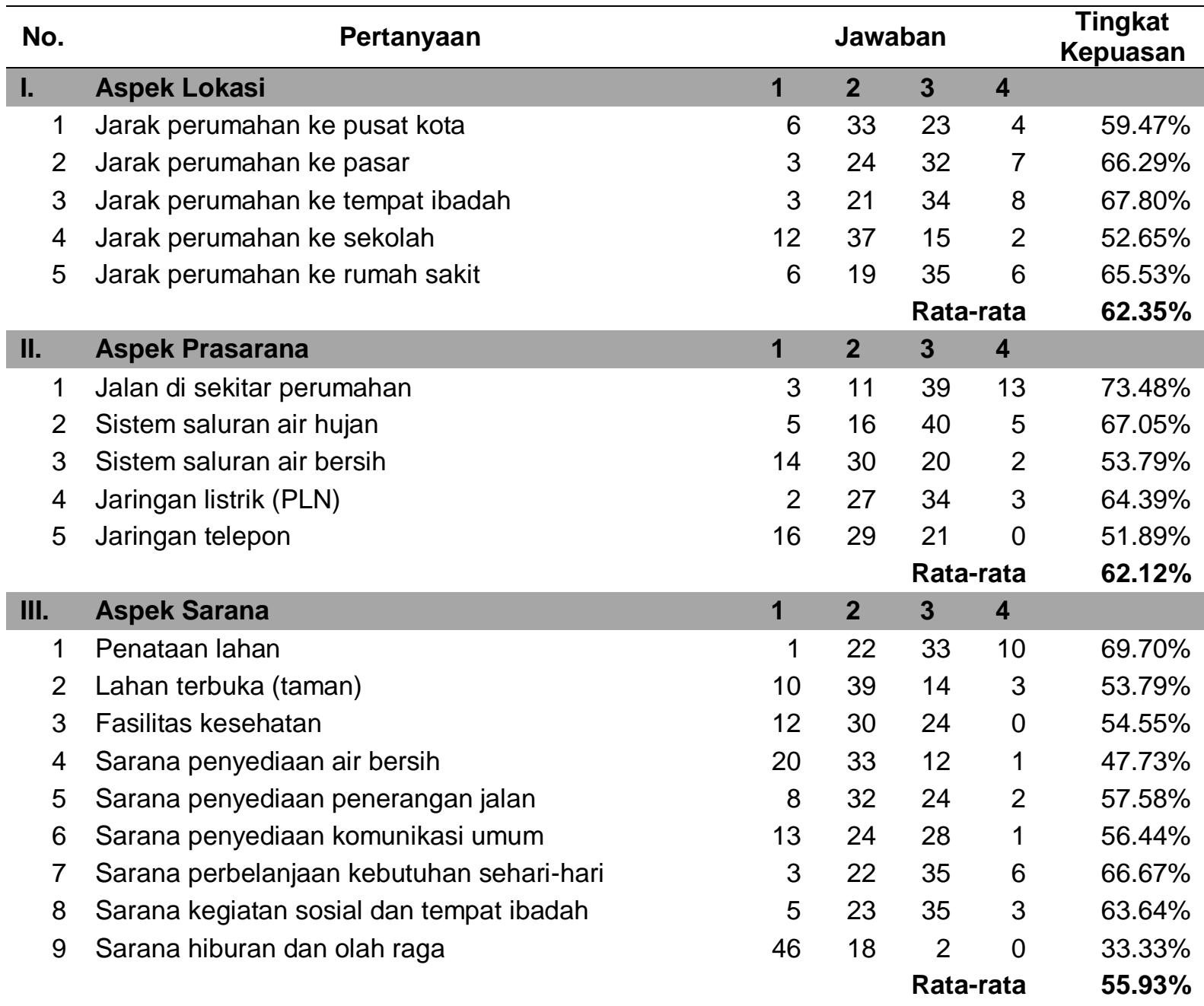




\begin{tabular}{|c|c|c|c|c|c|c|}
\hline \multirow{2}{*}{$\begin{array}{l}\text { No. } \\
\text { IV. }\end{array}$} & \multirow[t]{2}{*}{ Pertanyaan } & \multicolumn{4}{|c|}{ Jawaban } & \multirow[t]{2}{*}{$\begin{array}{c}\text { Tingkat } \\
\text { Kepuasan }\end{array}$} \\
\hline & & 1 & 2 & 3 & 4 & \\
\hline 1 & Ruang kosong di rumah & 13 & 27 & 23 & 3 & $56.06 \%$ \\
\hline 2 & Rancangan rumah sesuai awal transaksi & 5 & 22 & 38 & 1 & $63.26 \%$ \\
\hline 3 & Penataan sirkulasi ruang dalam rumah & 23 & 22 & 20 & 1 & $49.62 \%$ \\
\hline 4 & Penataan ruang luar & 6 & 34 & 26 & 0 & $57.58 \%$ \\
\hline 5 & Penataan ventilasi & 15 & 28 & 23 & 0 & $53.03 \%$ \\
\hline 6 & Kejelasan perletakan ruang & 3 & 29 & 33 & 1 & $62.12 \%$ \\
\hline 7 & Luas ruang tidur & 9 & 22 & 34 & 1 & $60.23 \%$ \\
\hline 8 & Luas dapur & 10 & 32 & 23 & 0 & $54.17 \%$ \\
\hline 9 & Luas ruang keluarga & 2 & 30 & 33 & 1 & $62.50 \%$ \\
\hline 10 & Luas ruang makan & 9 & 32 & 25 & 0 & $56.06 \%$ \\
\hline 11 & Luas taman & 10 & 32 & 24 & 0 & $55.30 \%$ \\
\hline \multirow[t]{2}{*}{12} & Warna cat bangunan & 12 & 25 & 26 & 3 & $57.58 \%$ \\
\hline & & & \multicolumn{3}{|c|}{ Rata-rata } & $57.29 \%$ \\
\hline V. & Aspek Harga & 1 & 2 & 3 & 4 & \\
\hline 1 & Harga termasuk sertifikat & 4 & 15 & 43 & 4 & $67.80 \%$ \\
\hline 2 & Harga termasuk IMB & 0 & 24 & 40 & 2 & $66.67 \%$ \\
\hline 3 & Harga akta jual beli & 1 & 21 & 41 & 3 & $67.42 \%$ \\
\hline 4 & Harga termasuk PDAM & 19 & 22 & 25 & 0 & $52.27 \%$ \\
\hline 5 & Harga termasuk biaya proses KPR & 8 & 28 & 30 & 0 & $58.33 \%$ \\
\hline 6 & Harga termasuk penyambungan PLN & 5 & 39 & 21 & 1 & $56.82 \%$ \\
\hline \multirow[t]{2}{*}{7} & Harga bangunan berubah & 9 & 23 & 33 & 1 & $59.85 \%$ \\
\hline & & & \multicolumn{3}{|c|}{ Rata-rata } & $61.31 \%$ \\
\hline VI. & Aspek Kualitas Bangunan & 1 & 2 & 3 & 4 & \\
\hline 1 & Kelengkapan bangunan & 3 & 29 & 33 & 1 & $62.12 \%$ \\
\hline 2 & Penerangan alami ruangan & 8 & 26 & 32 & 0 & $59.09 \%$ \\
\hline 3 & Penghawaan alami ruangan & 12 & 28 & 26 & 0 & $55.30 \%$ \\
\hline 4 & Penggunaan cat untuk dinding luar & 3 & 24 & 33 & 6 & $65.91 \%$ \\
\hline 5 & Penggunaan cat untuk dinding dalam & 6 & 22 & 36 & 2 & $62.88 \%$ \\
\hline 6 & Penggunaan cat kusen & 6 & 28 & 32 & 0 & $59.85 \%$ \\
\hline 7 & Penggunaan material kayu kusen, pintu, dan jendela & 2 & 18 & 41 & 6 & $70.08 \%$ \\
\hline 8 & Penggunaan material kayu rangka plafon dan atap & 11 & 22 & 33 & 0 & $58.33 \%$ \\
\hline 9 & Pelesteran dinding & 31 & 21 & 14 & 0 & $43.56 \%$ \\
\hline \multirow[t]{2}{*}{10} & Peningkatan mutu berpengaruh ke harga & 7 & 23 & 31 & 5 & $62.88 \%$ \\
\hline & & & \multicolumn{3}{|c|}{ Rata-rata } & $60.00 \%$ \\
\hline
\end{tabular}

Sumber: Hasil Pengumpulan dan Pengolahan Data

Ket: $1=$ Sangat Tidak Puas

$2=$ Tidak Puas

$3=$ Puas

$4=$ Sangat Puas

Berdasarkan hasil pengolahan data pada Tabel 3, dapat dilihat bahwa aspek lokasi tingkat kepuasan tertinggi adalah jarak perumahan ke tempat ibadah $(67,80 \%)$, sedangkan terendah adalah jarak perumahan ke sekolah (52,65\%). Hasil observasi menunjukkan bahwa tempat ibadah (masjid) terdapat di dalam kompleks

perumahan. Sedangkan sekolah jaraknya dari lokasi perumahan $5 \mathrm{~km}$ (SMAN 1 Manyar).

Aspek prasarana tingkat kepuasan tertinggi adalah jalan di sekitar perumahan (73.48\%), sedangkan tingkat kepuasan terendah adalah jaringan telepon (51.89\%). Hasil observasi menunjukkan bahwa sarana 
jalan di sekitar perumahan sangat baik dengan lebar $6 \mathrm{~m}$ dan telah diaspal hotmix. Jaringan telepon menempati peringkat terendah karena belum semua rumah dilewati oleh jaringan telepon, karena proses pembangunan masih terus berjalan.

Pada aspek sarana tingkat kepuasan tertinggi adalah penataan lahan $(69.70 \%)$, sedangkan terendah adalah sarana hiburan dan olah raga (33.33\%). Hasil observasi menunjukkan bahwa penataan lahan pada perumahan memang sudah baik dimana tersedia lahan untuk taman, lahan kegiatan sosial, lahan untuk tempat ibadah, lahan untuk bermain anak, lahan untuk olah raga, dan lahan untuk pendidikan prasekolah. Kepuasan konsumen untuk sarana hiburan dan olah raga sangat rendah, karena saat penelitian ini dilakukan proses pembangunan perumahan masih terus dilaksanakan sehingga sarana yang direncanakan belum sepenuhnya terbangun.

Untuk aspek desain tingkat kepuasan tertinggi adalah rancangan rumah sesuai dengan awal transaksi (63.26\%), sedangkan terendah adalah penataan sirkulasi ruang (49.62\%). Dari hasil observasi menunjukkan bahwa rumah yang terbangun memang sesuai dengan gambar denah dan tampak yang ditunjukkan pada awal transaksi, namun karena rumahnya tidak terlalu luas, maka konsumen merasa tidak puas dengan sirkulasi yang terjadi di dalam rumah.

Aspek harga tingkat kepuasan tertinggi adalah harga termasuk sertifikat $(67.80 \%)$, sedangkan terendah harga termasuk PDAM $(52.27 \%)$. Tingkat kepuasan konsumen terhadap harga sudah termasuk sertifikat tinggi, karena sertifikat merupakan bukti kepemilikan yang sah, sedangkan untuk PDAM rendah karena masih ada biaya tambahan lain yang harus dikeluarkan konsumen jika proses pemasangannya ingin dipercepat.

Untuk aspek kualitas tingkat kepuasan tertinggi adalah material kayu untuk kusen, pintu, dan jendela $(70.08 \%)$, sedangkan terendah adalah plesteran dinding (43.56\%). Hasil observasi menunjukkan bahwa kayu yang digunakan untuk kusen, pintu, dan jendela menggunakan kayu kamper sehingga tingkat kepuasan konsumen tinggi, sedangkan plesteran tembok sudah ada yang retak-retak.

Secara keseluruhan dapat dilihat bahwa tingkat kepuasan konsumen tertinggi adalah pada aspek prasarana dengan sub aspek jalan di sekitar perumahan (73,48\%). Tingkat kepuasan terendah adalah aspek sarana dengan sub aspek sarana hiburan dan olah raga $(33,33 \%)$. Aspek lokasi memiliki tingkat kepuasan rata-rata tertinggi (62,35\%), sedangkan tingkat kepuasan rata-rata terendah adalah aspek sarana (55,93\%). Rata-rata tingkat kepuasan penghuni untuk aspek yang dinilai adalah $59,83 \%$. Tingkat kepuasan konsumen untuk keenam aspek yang diteliti dapat dilihat pada Gambar 3.

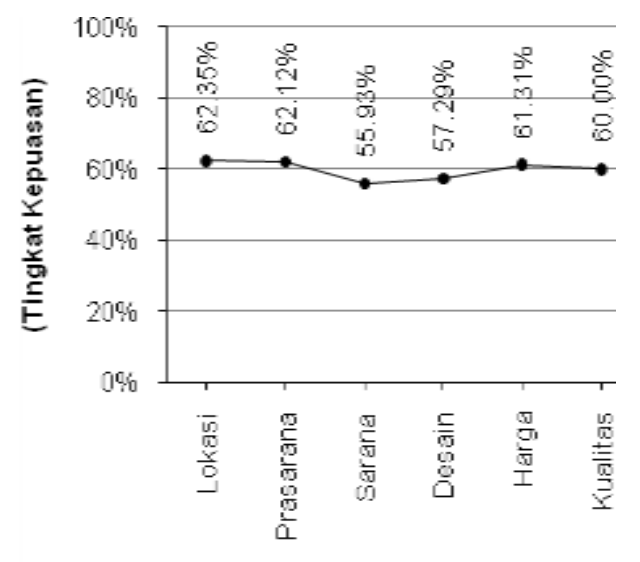

(Aspek Yang Dinilai)

Gambar 3. Grafik Rata - rata Tingkat Kepuasan

Namun demikian jika dilihat pada Gambar 3, maka sesungguhnya tidak terjadi perbedaan tingkat kepuasan yang signifikan diantara keenam aspek yang dinilai. Keenam aspek tersebut mendekati nilai rata-rata.

\section{Faktor Tingkat Kepuasan Konsumen}

Untuk mengetahui faktor mana yang sangat berpengaruh terhadap tingkat kepuasan konsumen maka digunakan regresi berganda. Agar dapat menggunakan regresi berganda terlebih dahulu harus dilakukan uji persyaratan regresi berganda dengan menggunakan Uji Autokorelasi.

Uji Autokorelasi dilakukan dengan hipotesis:

Ho : Tidak terjadi adanya autokorelasi diantara data pegamatan.

$\mathrm{Ha}$ : Terjadi adanya autokorelasi diantara data pegamatan

Ho diterima jika Nilai Durbin-Watson mendekati angka 2 (R. Gunawan Sudarmanto, 2005). Dengan bantuan SPSS, maka hasil Uji Autokorelasi dapat dilihat pada Tabel 4. 
Tabel 4. Hasil Uji Autokorelasi

Model Summary ${ }^{b}$

\begin{tabular}{cccccc}
\hline Model & $\mathrm{R}$ & $\begin{array}{c}\mathrm{R} \\
\text { Square }\end{array}$ & $\begin{array}{c}\text { Adjusted } \\
\mathrm{R} \text { Square }\end{array}$ & $\begin{array}{c}\text { Std. Eror of } \\
\text { the Estimate }\end{array}$ & $\begin{array}{c}\text { Durbin }-\mathrm{W} \\
\text { Aston }\end{array}$ \\
\hline 1 & $688^{\mathrm{a}}$ & 474 & 420 & 1.5224 & 2.098 \\
\hline Sumber: Hasil Pengolahan Data & & &
\end{tabular}

a. Predictors : (Constant), Kualitas, Prasarana, Harga, Lokasi, sarana, Desain

b. Dependent Variable : Kepuasan

Tabel 4 menunjukkan bahwa Nilai DurbinWatson adalah 2,098 (mendekati 2) sehingga Ho diterima yang berarti bahwa tidak terjadi autokorelasi antara data. Hal ini menunjukkan bahwa regresi berganda dapat digunakan untuk menentukan faktor yang sangat mempengaruhi tingkat kepuasan konsumen.

Persamaan regresi berganda yang digunakan adalah: dimana

$Y=a+b_{1} X_{1}+b_{2} X_{2}+b_{3} X_{3}+b_{4} X_{4}+b_{5} X_{5}+b_{6} X_{6}$

$\mathrm{Y}=$ Kepuasan Konsumen

$\mathrm{a}, \mathrm{b}=$ Parameter Variabel Bebas

$\mathrm{X}_{1}=$ Lokasi

$X_{2}=$ Prasarana

$\mathrm{X}_{3}=$ Sarana

$\mathrm{X}_{4}=$ Desain

$X_{5}=$ Harga

$X_{6}=$ Kualitas Rumah

Hasil regresi berganda dengan menggunakan SPSS dapat dilihat pada Tabel 5.

Tabel 5. Hasil Regresi Berganda

\section{Coefficients}

\begin{tabular}{|c|c|c|c|c|c|c|c|c|c|c|c|c|}
\hline \multirow{2}{*}{ Model } & \multicolumn{2}{|c|}{$\begin{array}{l}\text { Jnstandardized } \\
\text { Coefficients }\end{array}$} & \multirow{2}{*}{$\begin{array}{c}\text { Standard zed } \\
\text { Coefficients } \\
\text { Beta }\end{array}$} & \multirow{2}{*}{$\mathrm{t}$} & \multirow{2}{*}{ Sig } & \multicolumn{2}{|c|}{$\begin{array}{l}\text { Convidence } \\
\text { Interval }\end{array}$} & \multicolumn{3}{|c|}{ Correlations } & \multicolumn{2}{|c|}{ Ilinearity Statist } \\
\hline & B & $\begin{array}{l}\text { Std. } \\
\text { Eror }\end{array}$ & & & & $\begin{array}{l}\text { Ower } \\
\text { Boun }\end{array}$ & $\begin{array}{l}\text { Pper } \\
\text { Boun }\end{array}$ & $\begin{array}{l}\text { Ero- } \\
\text { orde }\end{array}$ & Partial & Part & Tolerancy & VIF \\
\hline Constant & 4.733 & 2.358 & & 2.007 & 049 & 014 & 9.452 & & & & & \\
\hline Lokasi & -128 & 137 & -106 & -934 & 354 & -402 & 146 & 189 & -121 & -088 & 692 & 1.444 \\
\hline Prasarana & -268 & 145 & -194 & -1.846 & 070 & -559 & 023 & -036 & -234 & -174 & 806 & 1.241 \\
\hline sarana & 184 & 087 & 250 & 2.110 & 039 & 009 & 358 & 436 & 265 & 199 & 633 & 1.580 \\
\hline Desain & 145 & 078 & 221 & 1.843 & 070 & -012 & 301 & 471 & 233 & 174 & 618 & 1.619 \\
\hline Harga & 184 & 080 & 233 & 2.300 & 025 & 024 & 344 & 430 & 287 & 217 & 867 & 1.153 \\
\hline kualitas & 194 & 076 & 314 & 2.540 & 014 & 041 & 347 & 551 & 314 & 240 & 583 & 1.714 \\
\hline
\end{tabular}

Sumber: Hasil Pengolahan Data

a. Dependent Variable : Kepuasan

Dari Tabel 5, maka diperoleh hasil sebagai berikut:

$Y=4,733-0,128 X_{1}-0,268 X_{2}+0,184 X_{3}+$ $0,145 X_{4}+0,184 X_{5}+0,194 X_{6}$

Variabel yang mempengaruhi tingkat kepuasan konsumen dapat dilihat pada hasil perhitungan uji keberartian koefisien regresi berganda (R. Gunawan Sudarmanto, 2005), seperti diperlihatkan pada Tabel 6, dengan hipotesis sebagai berikut:

Ho : Tidak ada pengaruh dari variabel bebas $(\mathrm{X})$ terhadap variabel terikat $(\mathrm{Y})$

$\mathrm{Ha}$ : Terdapat pengaruh dari variabel bebas $(\mathrm{X})$ terhadap variabel terikat $(\mathrm{Y})$

Dengan pengambilan keputusan:

1. Menolak Ho dan menerima Ha apabila signifikasi $t_{\text {hitung }}>t_{\text {tabel }}$.
2. Menerima Ho dan menolak Ha apabila signifikasi $t_{\text {hitung }}<\mathrm{t}_{\text {tabel }}$.

Hasil pembuktian tentang keberartian koefisien regresi berganda yang telah dilakukan, menunjukkan bahwa sebagian besar harga koefisien $t_{\text {hitung }}$ lebih besar dari harga koefisien $t_{\text {tabel }}$ pada $\mathrm{dk}=65$ dengan alpha $5 \%$. Berdasarkan hasil tersebut di atas maka dapat dikatakan bahwa aspek sarana, desain, harga, dan kualitas secara signifikan berpengaruh terhadap tingkat kepuasan konsumen. Sedangkan aspek lokasi dan prasarana tidak berpengaruh secara signifikan terhadap kepuasan konsumen karena memiliki nilai negatif. 
Tabel 6. Hasil Perhitungan Uji Keberartian Koefisien Regresi Berganda

\begin{tabular}{clccc}
\hline No. & $\begin{array}{c}\text { Variabel } \\
\text { Bebas }\end{array}$ & Significancy & \multicolumn{2}{c}{ Harga Koefisien t } \\
& thitung & $\mathrm{t}_{\text {tabel }}$ \\
\hline 1 & Lokasi & $-0,128$ & $-0,934$ & \\
2 & Prasarana & $-0,268$ & $-1,846$ & 1,66 \\
3 & Sarana & 0,184 & 2,110 & (dk $=$ \\
4 & Desain & 0,145 & 1,843 & dan \\
5 & Harga & 0,184 & 2,300 & alpha \\
6 & Kualitas & 0,194 & 2,540 & $=5 \%)$ \\
\hline
\end{tabular}

Sumber: Hasil Pengolahan Data

Untuk mengetahui aspek mana yang paling dominan mempengaruhi tingkat kepuasan konsumen adalah dengan melihat Standarized Coefficient Beta pada Tabel 5. Dengan mengabaikan tanda negatif (-) maka angka Standarized Coefficient Beta yang terbesar memiliki pengaruh yang lebih dominan. Secara berturut-turut aspek yang paling dominan dalam mempengaruhi tingkat kepuasan konsumen yang membeli dan mendiami Rumah Tipe 36 di Perumahan Pondok Permata Suci Gresik adalah aspek kualitas rumah $(0,314)$, aspek sarana $(0,250)$, aspek harga $(0,233)$, aspek desain $(0,221)$, aspek prasarana $(-0,194)$, dan aspek lokasi $(-0,106)$. Dengan demikian kualitas bangunan rumah sangat dominan dalam mempengaruhi tingkat kepuasan konsumen daripada pengaruh sarana, harga, desain, prasarana, dan lokasi.

\section{SIMPULAN DAN SARAN Simpulan}

Dari hasil penelitian dan pembahasan di atas, maka simpulan yang diambil adalah:

1. Tingkat kepuasan konsumen Perumahan Pondok Permata Suci Gresik ditinjau dari aspek lokasi $62,35 \%$, prasarana $62,12 \%$, sarana $55,93 \%$, desain $57,29 \%$, harga $61,31 \%$, dan kualitas bangunan rumah $60,00 \%$, dengan tingkat kepuasan ratarata $59,83 \%$.

2. Faktor yang sangat mempengaruhi tingkat kepuasan konsumen yang telah membeli dan mendiami Rumah Tipe 36 di Perumahan Pondok Permata Suci Gresik adalah kualitas bangunan rumah.

\section{Saran}

Agar tingkat kepuasan konsumen meningkat, maka disarankan:

1. Pembangunan sarana perumahan hendaklah dilakukan bersamaan dengan pembangunan rumah.

2. Kualitas rumah harus selalu menjadi perhatian pengembang karena sangat dominan dalam mempengaruhi tingkat kepuasan konsumen.

\section{DAFTAR PUSTAKA}

Anonimus. (1987). Keputusan Menteri Pekerjaan Umum Nomor: 378/KPTS/1987 Tentang Pengesahan 33 Standar Konstruksi Bangunan Indonesia, Departemen Pekerjaan Umum, Jakarta.

Anonimus. (1992). UU Nomor: 4 Tahun 1992 tentang Perumahan dan Pemukiman, Presiden Republik Indonesia, Jakarta.

Handi, Irawan. (2002). 10 Prinsip Kepuasan Pelanggan, PT. Gramedia, Jakarta.

Kodoatie, Robert J. (2000). Analisis Ekonomi Teknik, Andi, Yogyakarta.

Kwanda, Timoticin. (2001). Analisis Kepuasan Penghuni Perumahan Sederhana di Denpasar Berdasarkan Faktor Lokasi, Prasarana, Sarana, Kualitas Bangunan, Desain dan Harga, Jurnal Teknik Arsitektur (Online), Vol. 29, No. 2, (http://puslit.petra.ac.id/journals/architecture/ analisis.html).

M, Suparno Sastra \& Marlina, Endi. (2006). Perencanaan dan Pengembangan Perumahan, Andi Offset, Yogyakarta.

Sudarmanto, R. Gunawan. (2005). Analisis Regresi Linier Berganda dengan SPSS, Andi Offset, Yogyakarta.

Supranto, Johanes. (2001). Pengukuran Tingkat Kepuasan Pelanggan, Rineka Cipta, Jakarta. 